\title{
Mineralogy and Petrography of Gulneri Formation in Sulaimaniya Area, North East of Iraq, (Kurdistan)
}

\author{
Al-Khafaji S. J. ${ }^{1}$, Al- Saad A.L. ${ }^{2}$ \\ ${ }^{1,2}$ Department of Geology, College of Science, Universityof Basrah, Basrah, Iraq
}

*Corresponding Author: Al- Saad A.L., Department of Geology, College of Science, Universityof Basrah, Basrah, Iraq

\begin{abstract}
This study focused on mineralogy, petrography andmicrofacies analysis of Twenty four samples of limestone, marl to marly limestone and shale-likelithofacies of Gulneriformation which exposed in Dokan, Azmir, Weller and Pushen in Sulaymaniyah area north-east Iraq in order to identify the mineralogical content and diagenetic processes that affect the formation aiming to detect the depositional environment of GulneriFormation. The X-Ray diffraction analysis shows that $67 \%$ of the samples are composed of calcite followed by $33 \%$ quartz, the insoluble residue indicated the presence of quartz and clay minerals represents by palygorskite and illite, palygorskite indicate that the formation was deposited in inner warm marine shelf to dray or semi dray environment, illite indicate the enrichment of Potassium in the environment. The presence of wacky limestone, bioclastic lime mudstone, andbioclastic lime packstonemicrofacies reflect the deposition of formation in shallow to deep open shelf environments. Cementation, recrystallization, silicification, pyritization and mechanical-chemical compaction are the main diagenetic processes that affect the rock formation.
\end{abstract}

Keywords: Gulneri, Sulaimaniya, lithofacies, recrystallization, packstone microfacies.

\section{INTRODUCTION}

Gulneri Formation is one of the Cenomanian-Early Turonian sequence in Iraq which was first described by Lancaster Jones (1957) in (Bellenet al., 1959) in Dokan Dam site north-east Iraq, where it consists mainly of about 1.2-2 m of marl and marly limestone with no more than $20 \%$ of fissile like shale? (Karim and Taha, 2009). The Formation have early Turonian age according to Abawiet.al 2006, the distribution of the formation is almost unknown in north Iraq but there is some exposures of the formation noticed in the area of the study at the flanks of Azmir anticline represents Azmir area, Weller village, Pushen village as well as the Dokan site dam which previously identified by many researchers, the formation is separated by unconformities with both the overlying limestone of Kometan Formation and underlying limestone of Dokan Formation. The goal of the present study is to identify the main minerals constituents of Gulneri formation in addition to detect the main microfacies and diageneticprocesses that affected the rocks of the formation.

\subsection{Study Area and Geological Setting}

The studied sections are located about 7-10 km northeast of Sulaimaniya governorates in Azmir anticline between the high folded zone and imbricated zone at latitudes N 35o 07- 90= and 36o 30$60=$ and longitudes E 46o 44- 22= and 44 o 18-53= (Fig.1 and Fig.2). The area includes a series of high mountains forming anticlines and synclines have trending Northwest-Southeast, the highest mountainsarepiramagroon, Asos, Karokh, Kura Kazhaw, and Shinarwe. Which have more than $200 \mathrm{~m}$ above sea level (Karim, 2009) Azmir fold is a major symmetrical anticline in the study area which is directed parallel to Zagros chains extending NW-SE,(Ma'ala et al., 2004). There are some exposed Cretaceous formations in Azmir anticline represented by Balambo,Dokan,Gulneri, Kometan,Shiranish and Tanjero formation where the Kometan formation represents the major part of Azmiranticline, and Balambo formation represents the core of anticline, The average of dip angle measured on Gulneri, Dokan and Kometan formations is between 70 to 80 degree. Most of the anticline in the area was eroded and formed deep valleys and plains which have dendritic drainage patterns and drain towards 
the southwest,tectonically the area located in the high -imbricated and thrust zone (Buday and Jassim 1987).

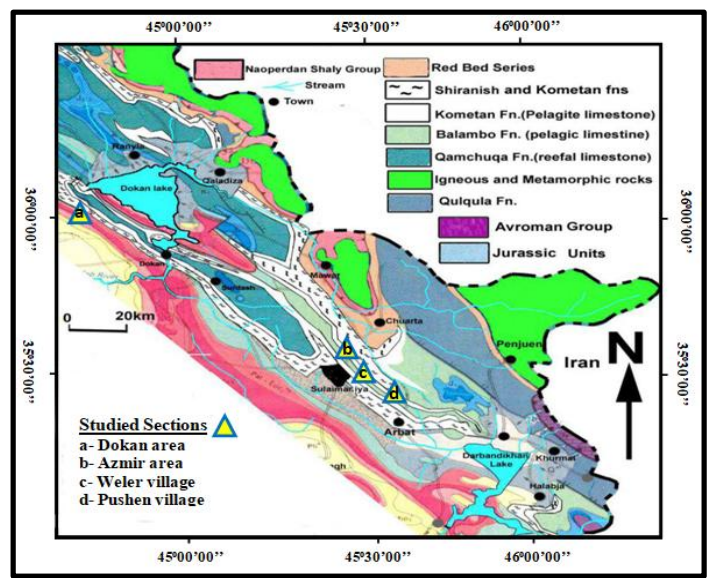

Fig1. Geological map of the studied area (modified from Sissakian, 2000 and Karimet al., 2011) shows the studied sections of Gulneri Formation.

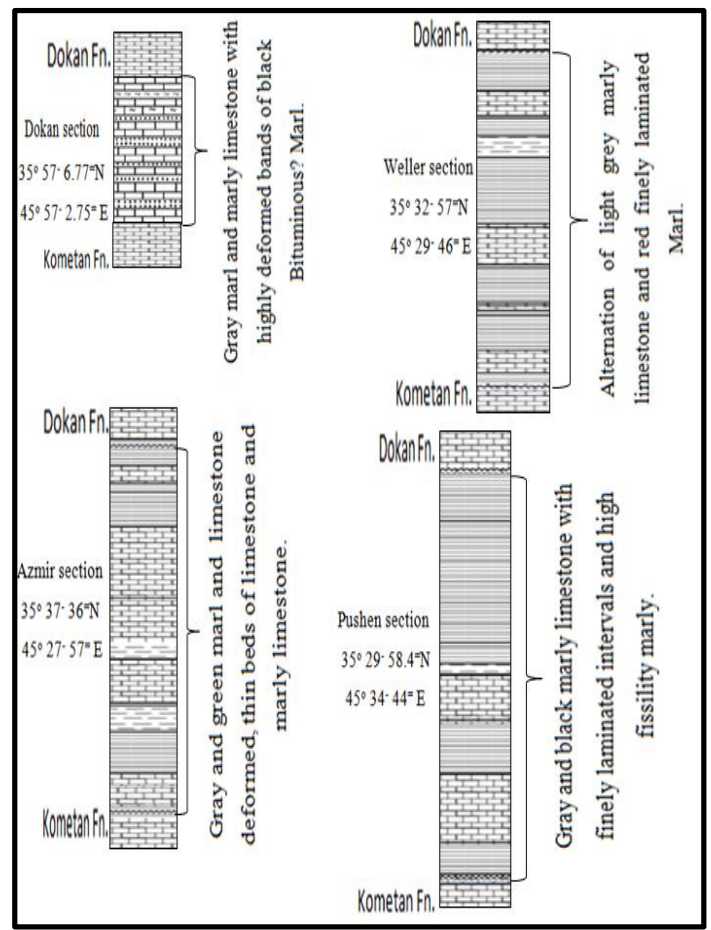

Fig2. Studied sections of Gulneri formation.

\section{Materials AND Methods}

\subsection{Mineralogical Analysis}

\subsubsection{Non- clay minerals (carbonate and other associated minerals)}

More than Twenty four samples were broken and grinded by using a grinding machine and then screened to 75 microns. Twenty four bulk powder samples were analyzed by using XRD techniques type and scannedat $(2 \theta)$ range from $2^{\circ}-60^{\circ}$ degrees. The instrument type used is broker D2 phaser in the Iraqi German laboratory/University of Baghdad/college of science/Department of geology. The minerals were identified according to the methodwhich is reported in AL-Khafaji, (1989).

\subsubsection{Clay Minerals}

Four samples were selected and grounded to 250microns in order to achieve good separation of clay fraction from carbonates using Ostrom method (1961)to gain suspended clay fractions and then the suspended clay fractions were collected to prepare three different oriented slides:

A-Normal slides $(\mathrm{N})$ 
B-Heated slides to $550^{\circ} \mathrm{C}(\mathrm{H})$

C-Ethel-glycolate slides (EG) at 1 hour.

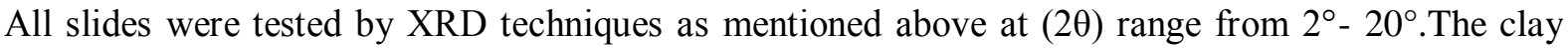
minerals were identified according to Carver, 1971 in Al-Khafaji, (1989).

\subsubsection{Insoluble Residue (\%I.R.)}

Insoluble residue was separated from carbonate rocks according to Ellingboeand Wilson, (1964), Lumusden, (1974). The percentages of insoluble residue calculated according to the following equation:

$$
\% \text { insoluble residue }=\frac{\text { weight of } \mathrm{I} . \mathrm{R}(\mathrm{gm})}{\text { total weight of } \operatorname{sample}(\mathrm{gm})} * 100
$$

Where:

The weight of (I.R) = weight of the filter paper and weight of I.R -the weight of the filter paper without samples and then the insoluble residue was examined using XRD techniques to determine their mineralogy.

\subsubsection{Petrographic Examinations}

Thin sections were preparedto represent 4 studied sections, atDepartment of Geology, College of Sciences of Baghdad University. Polarized microscope (Leitz. Polarizing microscope. LA PRO LUX 11 Germany), was used to identify, texture, mineral components, diagenetic processes, and microfacies.

\section{RESULTS AND DISCUSSION}

\subsection{Lithofacies of Gulneri Formation}

\subsubsection{Limestone Lithofacies}

This facies is considered as the more important facies of Gulneri formation. Its thickness ranges from (1-2.5m) and observed in the four studied sections. The facies is mainly composed of hard to very hard white to gray limestone intercalated by marl and thin like shale (Fig. 3).

\subsubsection{Marl Lithofacies}

This facies exists as a succession of limestone and marl units. Its color ranges from yellowish green to reddish brown and dark grey (Fig. 4). The thickness of this facies ranges from $(0.25-1.5 \mathrm{~m})$ with a hardness ranges from soft to medium. It occurs in the bottom and middle parts of Gulneri Formation sections.

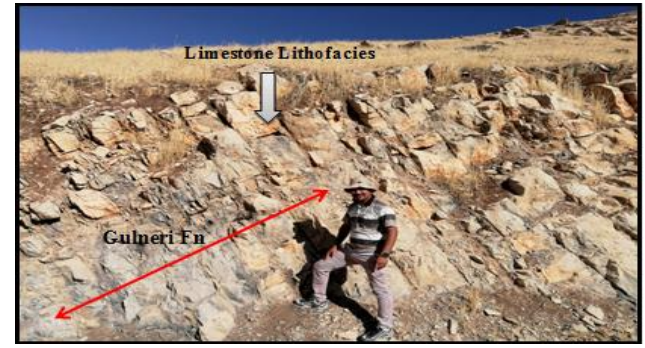

Fig3. Limestone lithofacies of GulneriFn.(Pushen section).

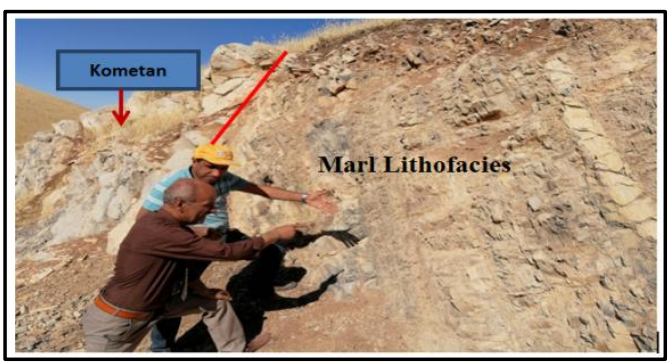

Fig4. Marllithofacies of GulneriFn.(Pushen section). 


\subsubsection{Shale Like?Lithofacies}

This facies exists as thin beds between the succession of limestone and marl lithofacies, its color extends from black to dark grey and a thickness of 0.7-1 m.Its toughness ranges from soft to medium (Fig. 5),it occurs in the lower and upper parts of Gulneri Formation sections. This facies showed laminated features and have black or dark gray in color is most probably due to the presence of the organic matter. According to Selley (2000), the black shales clearly indicate deposition in various water depths and environments that include lakes, lagoons, continental shelves, and deep oceans. Shales are formed under any environmental conditions in which fine sediments are abundant and water energy is sufficiently low allowing the settling of suspended fine silt and clay. Potter et. al(1980) mentioned three major marine types of shale: inner shelf marine, outer shelf marine,and deep sea. carbonate-free and often rich in organic matter, it is also indicated by the presence of grey and black color and thin lamina of marl.

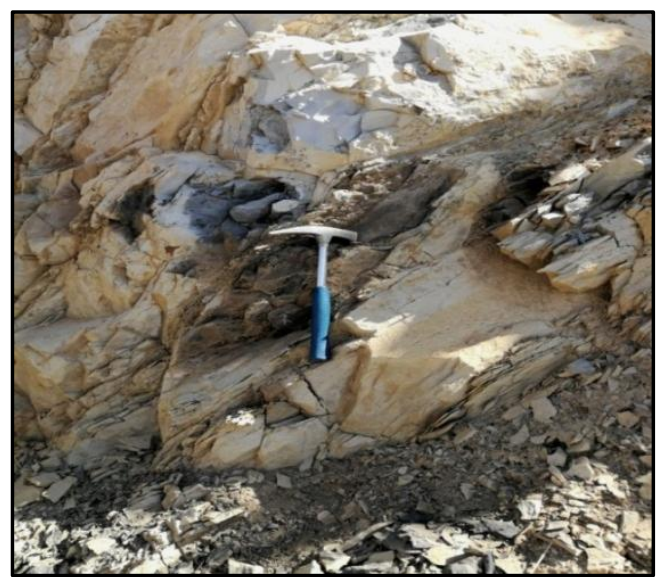

Fig5. Shale like lithofacies of Gulneri Fn. (Azmir section).

\section{Mineralogy OF GULNERI Formation}

The results of X-ray diffraction analysis showed that calcite and quartz are the dominant minerals in allfacies along with the subordinate by palygorskite and illite as clay minerals. Calcite was identified by the main reflections (104): $\mathrm{d}=\left(3.04 \mathrm{~A}^{\circ}, 2.29 \mathrm{~A}^{\circ}, 2.1 \mathrm{~A}^{\circ}, 1.91 \mathrm{~A}^{\circ}, 1.8 \mathrm{~A}^{\circ}\right)$, and the average content of calcite is $66.7 \%$ in bulk samples with a range of $45.83-88.24 \%$, while the average content of quartz is $33.2 \%$ with a range of 11.76-54.17\% havethe main reflections (104): $\mathrm{d}=\left(3.34 \mathrm{~A}^{\mathrm{o}}, 4.2 \mathrm{~A}^{\mathrm{o}}, 2.4 \mathrm{~A}^{\mathrm{o}}\right.$, $2.2 \mathrm{~A}^{\circ}$ ) (Table 1), (Fig.6). Palygorskiteidentifiedatreflection 10.5 and $4.5 \mathrm{~A}^{\circ}$, Illiteappear at reflections 10.0 and $5.0 \mathrm{~A}^{\circ}$ (Fig.7).Palygorskite indicate the formation was deposited in marine environments while illite indicate may be formed under marine environment of deep burial of sediments that enriched in pottassium. The mineralogy of insoluble residueis mainly quartz with lesser content of clay minerals (Palygorskite and Illite), (Fig. 8) the high percent of insoluble residueindicate the basinal environment of Gulneri formation.

Table1. Relatively percentages of the non-clay minerals and insoluble residue in some selected samples.

\begin{tabular}{|c|c|c|c|}
\hline \multirow[t]{2}{*}{ Sample No. } & \multicolumn{2}{|c|}{ Non-clay minerals } & \multirow[t]{2}{*}{ I.R $\%$} \\
\hline & \begin{tabular}{|l|} 
Calcite \\
\end{tabular} & Quartz & \\
\hline \begin{tabular}{|l|} 
B.s.1 \\
\end{tabular} & $71 \%$ & $28.4 \%$ & - \\
\hline \begin{tabular}{|l|} 
B.s.11 \\
\end{tabular} & $45.83 \%$ & $54.17 \%$ & 35.7 \\
\hline \begin{tabular}{|l|} 
B.s.15 \\
\end{tabular} & $81.58 \%$ & $18.42 \%$ & - \\
\hline \begin{tabular}{|l|} 
C.s.5 \\
\end{tabular} & $56 \%$ & $44 \%$ & 41.6 \\
\hline C.s10 & \begin{tabular}{|l|}
$\% 88.24$ \\
\end{tabular} & $11.76 \%$ & - \\
\hline \begin{tabular}{|l|} 
C.s.16 \\
\end{tabular} & $65.75 \%$ & $34.25 \%$ & - \\
\hline \begin{tabular}{|l|} 
D.s.2 \\
\end{tabular} & \begin{tabular}{|l|}
$\% 56.36$ \\
\end{tabular} & $43.64 \%$ & 50.4 \\
\hline \begin{tabular}{|l|} 
D.s.7 \\
\end{tabular} & $\%$ \%53.97 & $\% 46.03$ & 37.4 \\
\hline \begin{tabular}{|l|} 
D.s.11 \\
\end{tabular} & $81.82 \%$ & $18.18 \%$ & - \\
\hline Average & 66.72 & 33.2 & 41.2 \\
\hline
\end{tabular}




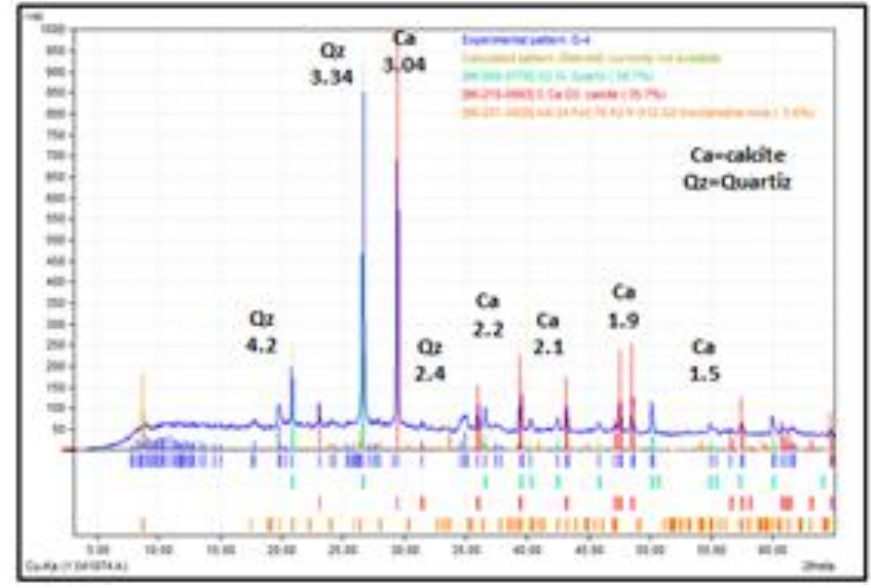

Fig6. X-ray diffractogram of Bulk sample No. (D.s.4).

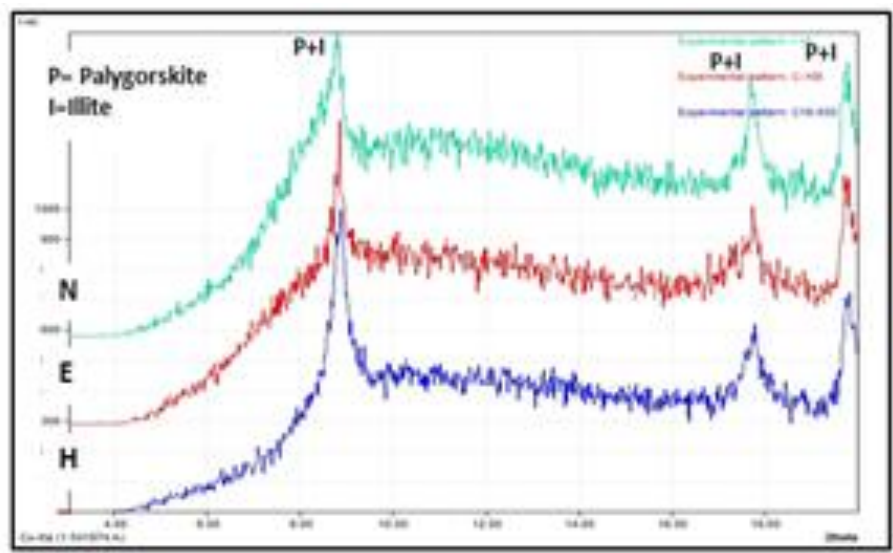

Fig7. X-ray diffractometer of clay minerals sample No. (C 16).

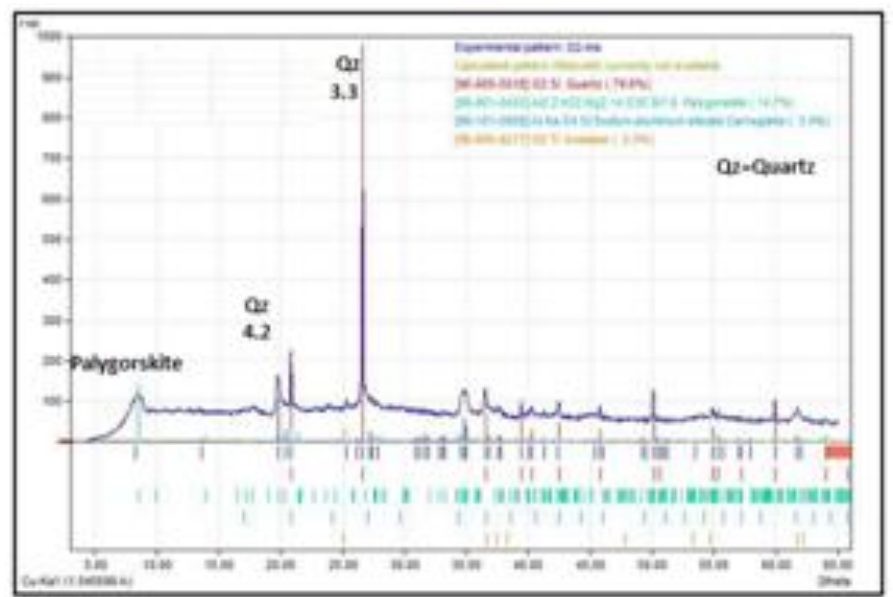

Fig8. XRD pattern for insoluble residue section $D$.

\subsection{Microfacies of Gulneri Formation}

Dunham classification (1962) presented a different facies type and it is used as an environmental indicator in the current study. Flugel, (2004), used the term microfacies in petrographic and paleontological studiesPresently, however, "microfacies" is regarded as the total of all sediment logical and paleontological data can be described and classified from thin sections, polished slabs or rock samples. Wilson's standard for microfacies (1975) was used to classify and identify the microfacies recorded in limestone units of Gulneri formation:

1- Mudstone Microfacies.

2- Bioclastic WackestoneMicrofacies.

3- Bioclastic PackstoneMicrofacies. 


\subsubsection{Mudstone Microfacies}

This microfaciesare common facies and constitute about $44 \%$ of the total thickness of the Gulneri formation. It is composed essentially of mud matrix and few angular to sub-angular silt-sized detrital quartz and grains of bioclasts and consists mainly of micrite (plate. 1. E), which is slightly affected by the processes of recrystallization, solution and compaction diagenesis. The mud matrix also consists of clay and iron oxide minerals (plate. 1. D). Planktonic foraminifera as Globigerina and Globotraaca are the common allochems with the presence of foraminifera (plate. 2.A). This faciesappears in the middle and the upper parts of the Gulneri Formation. The abundance of micrite and the occasional presence of planktonic forams suggest that this facies is supposed to be deposited in a deep basinal environment. Wilson(1975) mentioned similar kind to this facies as a deep and open marine environment where Kenteret al,. (2004) pointed out that foraminifera and minor skeletal grains are the dominate lithofacies in the deep basinal environment. This facies reflects deposition in a quiet deep marine environment this facies similar to SMF type (1), of Wilson, 1975, (Plate 1).

\subsubsection{Bioclastic Wackestonemicrofacies}

The skeletal component of this facies is up to (25\%); planktonic is the main one supported by mud (mud supported). The groundmass is composed of micrite. Wackestone widely distributed in the Gulneri formation and most of the studied sections contain this facies. Mineralogical constituents are calcite (micrite), (Plate 2.A) and non-carbonates such as quartz, iron oxides. The later exists in a little amount as bioclastsforms. In this facies, the grains of wackestone usually make up $(10-15 \%)$ in a micritic matrix. Skeletal grains include Globigerina and Heterohelix (plate 2.B). The matrix consists mainly of micrite. This facies occurs in the lower and upper parts of Gulneri Formation section, it reflects deposition in medium-energy deep marine neritic or in open sea shelf, similar to SMF type (8), of Wilson, 1975, (Plate 2).
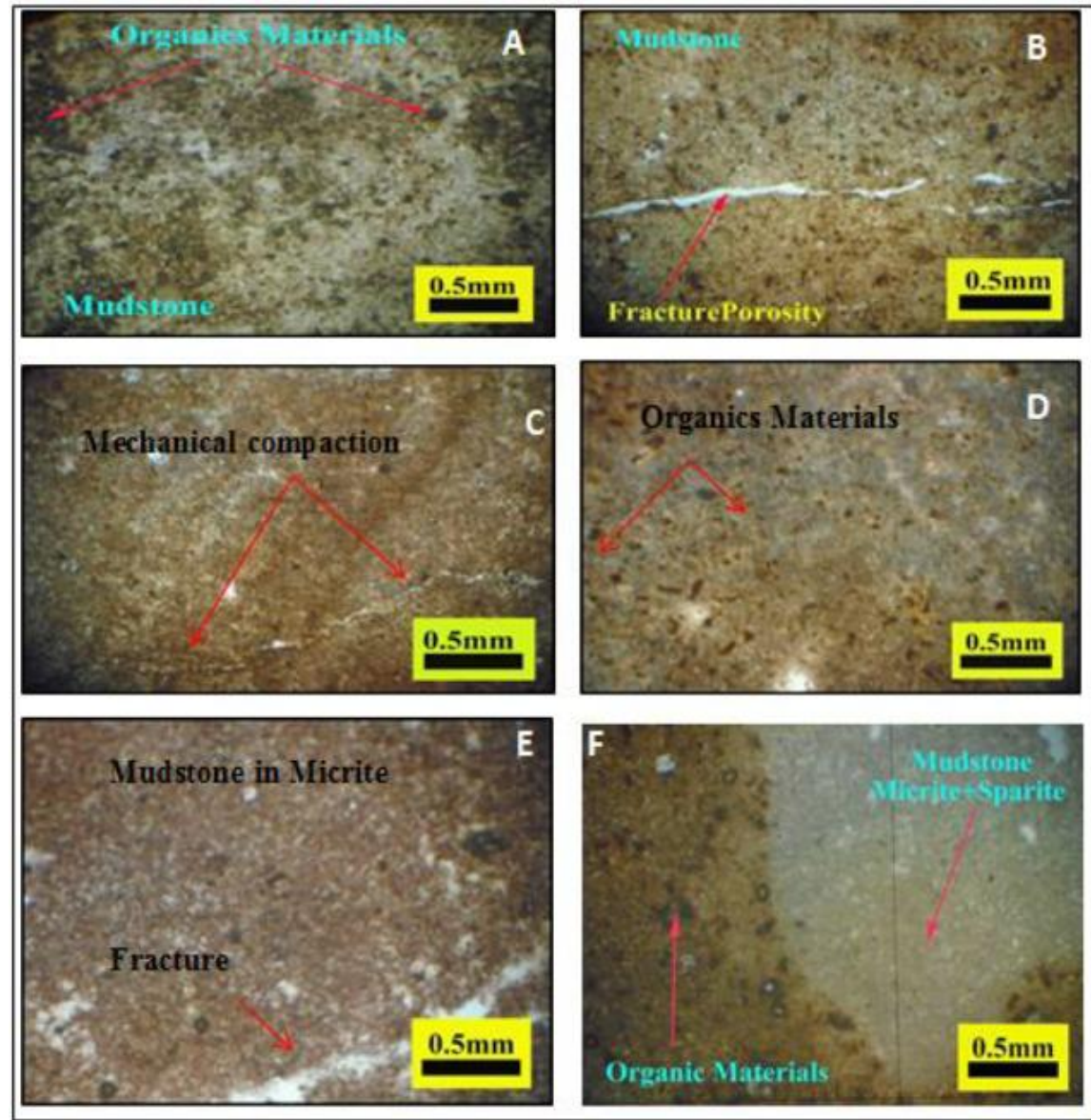

\section{Plate1}

A: Mudstone microfacies and organic materials with micrite as a matrix and spare inside the vugs in Azmir section.

B: Mudstone microfacies with fracture porosity in Azmir section. 
C: Mudstone microfacies with a large ratio of micrite and a low ratio of microsparite inside with affected by mechanical compaction in Weller section.

D: Mudstone microfacies and organic materials in the Weller section.

E: Mudstone microfacies in micrite in Pushen section.

F: Organic materials with micrite, sparite in Azmir section.

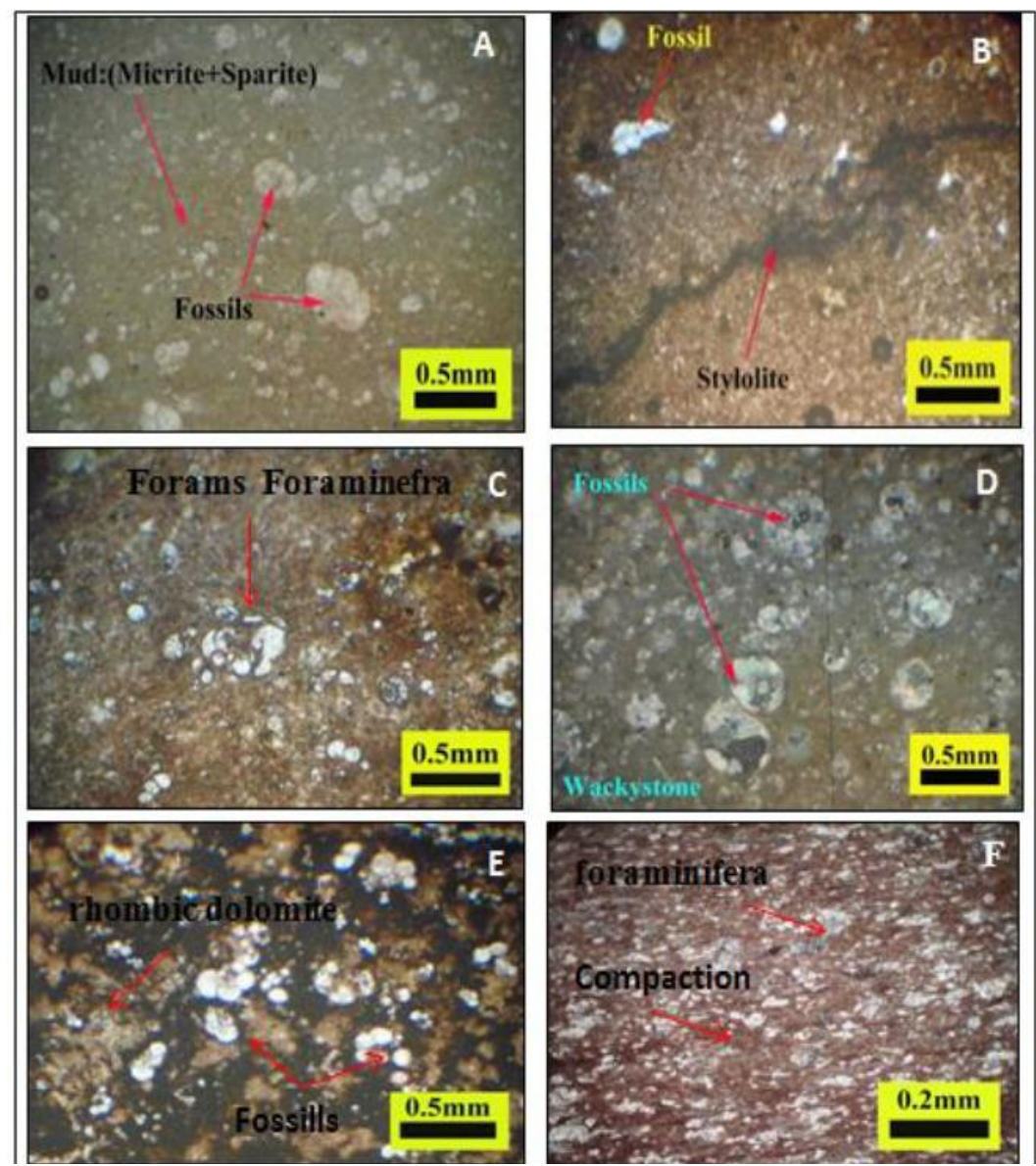

\section{Plate2}

A: Planktonic foraminifera as Globigerina with calcite a size of micrite and spare in a wackestone microfacies in Azmir section.

B:Planktonic foraminifera as Heterohelix with zigzag sutures or stylolitesin Azmir section.

C: Planktonicforaminifera (forams) as a result of dissolution processes with a wackestone microfacies in Weller section.

D: Planktonic foraminifera as Globigerina mixed with calcite grains in a wackestonemicrofacies in Azmir section.

E: Planktonic foraminifera as Globigerina with rhombic dolomite ramen with iron oxides in Pushen section.

F: Orientation Planktonic foraminifera as a result of mechanical compaction with a wackestone microfacies in the lower of Dokan section.

\subsubsection{Bioclastic Packstonemicrofacies}

It is composed of grains supporting each other (grains supported) with micrite and sparry grains. Skeletal components are of (65-90\%) range of the whole components. The grains later affected by recrystallization. Moreover, most of the micrite are recrystallized to microsparite then later to sparry grains (plate 3.A), this facies occurs in most of the four studied sections of GulneriFormation. It is characterized by an abundance of planktonic foraminifera like Globotraaca, Globigerina, and Heterohelix (plate 3.C and D), usually, planktonic express to the depths ranges between $200-2000 \mathrm{~m}$ 
(Selly, 2000). It is suggested that this facies is most probably deposited in a relatively shallow open marine or in a deep shelf margin (Fig. 8) similar to SMF type (3) of Wilson, 1975, (Plate 3).

\subsection{Diagenetic processes}

Diagenesis of carbonate rock is more varied than that of clastic rocks particularly, because of the metastable nature of carbonate minerals (Bathurst, 1975). Diagenetic processes include physical, chemical and biological changes affecting sediments since their deposition, then lithification and emergence on ground surface under normal pressure and/or heat (Larsen and Chilingar, 1979). Rhymond (1995) defined diagenesis as all physical, chemical and biological processes that collectively result in the transformation of sediment into sedimentary rocks. Selly, (2000), Tucker (1988) stated that diagenesis fabrics can be an important indication to both the depositional environment of the sediment and to the chemistry of a variety of fluids, which have been flushed through the sediment during burial. Mineralogical change can also be used to indicate the temperature and the depth of burial. These diagenetic changes may take place in the submarine, subaerial fresh water and subsurface environments (Larsen and Chilingar, 1979). The studied samples of Gulneri formation have been subjected to some diagenetic processes through their geologic history. The following diagenetic processes are thought to be the main ones that observed in the studied sample of Gulneri Formation:

\subsection{Compaction}

Flugel (2004) mentioned that there are two types of compaction, mechanical and chemical compaction and listed some factors that cause an increase in compaction such as:

- The ratio of fine to coarse particles.

- Amount of clay material.

- Increase in void ratio.

- Increase in a load of overburden.

a) Mechanical compaction: it occurs due to mechanical processes, causing reduction of pore space and expulsion of interstitial fluids resulting from grain rearrangements under load. Compaction is greatest and important only in the finest grained sediments. The compaction of sediments is predominantly caused by the overburden loading, sometimes because of high rates of deposition in rapidly subsiding basins (Flugel, 2010). The sediments then may remain over-pressured at depths with relatively high pore pressures, such that they never get compacted to the expected extent (Greensmith, 1978). In the studied samples, there is a noticeable effect of compaction by pressure represented by the orientation of the fossils (plate1.C), (plate2. F).

b) Chemical compaction: chemical compaction and pressure solution of grains and sediments is a significant cause of $\mathrm{CaCO}_{3}$ cement (Flugel, 2004). Under conditions in which the pore fluid pressure is less than the lithostatic pressure, there will be a preferential dissolution of grains at high-stress points where they touch (Flugel, 2010). The pressure solution structure in the studied samples includes stylolitization. It is appeared in Azmir Section at the lower part and not detected in the all Gulneri Sections, while the zigzag sutures appear clearly in this section (plate 2.B); the stylolite transect the grains, rock fabric, cement and matrix indiscriminately (Trurnit, 1968). Irregular stylolites are observed in Gulneri Formation studied samples (Plate3.F). That is mean in the present study area, the Gulneri carbonate is subjected to both chemical and physical compaction. The criteria used to estimate the effect of physical compaction is the preferred orientation of skeletal grains parallel to the bedding, whereas the chemical compaction is represented by the presence of stylolites. The main kinds of stylolites recognized in studied sections are irregular low amplitude (plate 3F), irregular high peak amplitude (plate 4B), parallel sets of high peak amplitude and parallel sets of horizontal stylolite. Depending on the classification of Longan and Semeniuk (1976) Stylolite surface are the sites of accumulation of insoluble residues (clay, iron oxides and others) as the rock closes up, that's what makes the stylolite dark.

\subsection{Dissolution}

The dissolution is an important process which is shown in most shells of fossils, it is the result of solution condition of unstable minerals (aragonite or high $\mathrm{Mg}$ calcite) and the chemistry of the pore 
water. Carbonate solubility increases with decreasing temperature and increasing acidity (Nicholes, 2009). Dissolution is less intensive in deep burial realm than in the meteoric realm for two reasons, firstly most aragonite and high $\mathrm{Mg}$ calcite may already have been converted into more stable calcite in meteoric realm secondly increasing temperature with depth decreases the solubility of all carbonate minerals; but dissolution may occur at depth if enough $\mathrm{CO}_{2}$ is added to pore water, as a result of burial decay of organic matter to overcome the decrease in solubility resulting from creased temperature (Boggs,1995). In Gulneri formation dissolution israther selective asit is much more frequent in fossils than the groundmass. Planktonic foram tests are generally less resistant to dissolution than benthic foraminifera (Berger and Piper, 1972) (Plate4.E).

\subsection{Recrystallization}

This process is indicated by the presence of fine calcite that recrystallized from very fine and fine to medium calcite. The recrystallization process was observed in the studied samples and is represented by recrystallization of micritic to microsparite and sparry calcite (plate 3.A). This is indicated by the presence of micrite as inclusion in the sparry grains and curved boundaries of the sparry calcite grain. Some fossils were observed to be affected by the recrystallization of calcite grain (plate $2 \mathrm{~A}$ ).

\subsection{Cementation}

Cementation is diagenetic processes by which voids and porosity are filled by sparry calcite during the deposition by filling the interparticle porosity or after deposition by filling the pore space resulting from dissolution or fracture and joints resulting from compaction (Longman, 1980). The important cement type in the Gulneri carbonate rocks is blocky cement. They are big calcite crystals which reflect slow crystallization of undersaturated solution and formed at late stages of diagenetic history. This process represents a freshwater phreatic zone (Longman, 1980). In the studied succession, this cement was recognized in many horizons as big crystals filling fractures, vugs, and channel inside skeletal grains like Globotraaca (Plate 2 D).

\subsection{Micritization}

Micritization is the earliest diagenetic process developed during postdepositional algal and bacterial activities (Bathurst, 1975), in a stagnant marine phreatic zone (Longman, 1980). Micritization in studied thin sections preferentially affected by the planktonic foraminifera, mainly (Diatomic fossils) (Plate 3.A,C). Rocks may almost completely change into micrite by processes called Micritization while borings are less intensive only a thin micrite rim to micrite envelope may be produced around the grain. Two possible mechanisms are believed to be responsible for the precipitation of calcium carbonate in the tubes of algal bores (Plate 4.D). The first process is inorganic precipitation promoted by the presence of special physicochemical micro-movement with the bores (Degroot, 1967 and Shinn, 1969). The second is caused by the metabolism of algae through bacterial growth (Shearman, 1969 in Dabbag, 2006). It is evident from the partly micritized grains that the replacement process always starts from the outer margins to produce a micrite envelope enclosing a residual core of unaltered skeletal carbonate or its cast if leached and later infilled with sparry calcite cement. This process is irregularly distributed throughout the Gulneri succession (Plate 4.D).

\subsection{Silicification}

Silicification can take place during early or late diagenesis; it takes the form of selective replacement of fossils (Tucker, 1988). Silicification in Gulneri sections is a common diagenetic process, which occurs particularly within the upper part of the formation. The source of silica probablywas derived by post-mortem dissolution of siliceous organisms (radiolaria) trapped in the sediment or the corrosion of quartz and clay minerals at high ${ }_{\mathrm{p}} \mathrm{H}$; when ${ }_{\mathrm{p}} \mathrm{H}$ decreases, precipitation of dissolved silica occurs. Moreover, the silica precipitation is produced by the decreases in temperature (Engelhardt, 1977), (plate 2. A).

\subsection{Pyritization}

The most common pyrite forms noticed in all sections are framboidal pyrite in Gulneri Formation that is shown by thin section (Plate 4.C). The presence of framboidal pyrites in the study sedimentary rock sequences denotes the predominance of reducing environment during the deposition; the framboidal pyrite is commonly considered as a vital evidence of environmental conditions during deposition of marine sediments and discrimination between anoxic-euxinic and toxic environments in the water column (Wilkin et al. 1996, Suits and Wilkin 1998, Wilkin and Arthur 2001, Henderson 2002, Bond et al.2004) (plate 3.B, E). Pyrite is considered as an authigenic mineral that grouses after sediments 
deposition, authigenic pyrite commonly from under reducing conditions replacing organic material (Flugel, 2010).

\subsection{Dolomitization}

Dolomitization is a process whereby limestone or it is precursor or sediments completely or partly converted to dolomite by replacement of original $\mathrm{CaCO}_{3}$ by $\mathrm{MgCO}_{3}$ through the action of Mg-bearing water (Flugel, 2010). Dolomitization process is very limited in Gulneri formation samples. It is observed difficulty in 1-2 samples. Which represented by some number of rhombic dolomite randomly rimed with iron oxides, (Plate 4.F). The large grains of dolomite (rhombic) most probably indicated that the dolomitization is late diagenetic in origin.

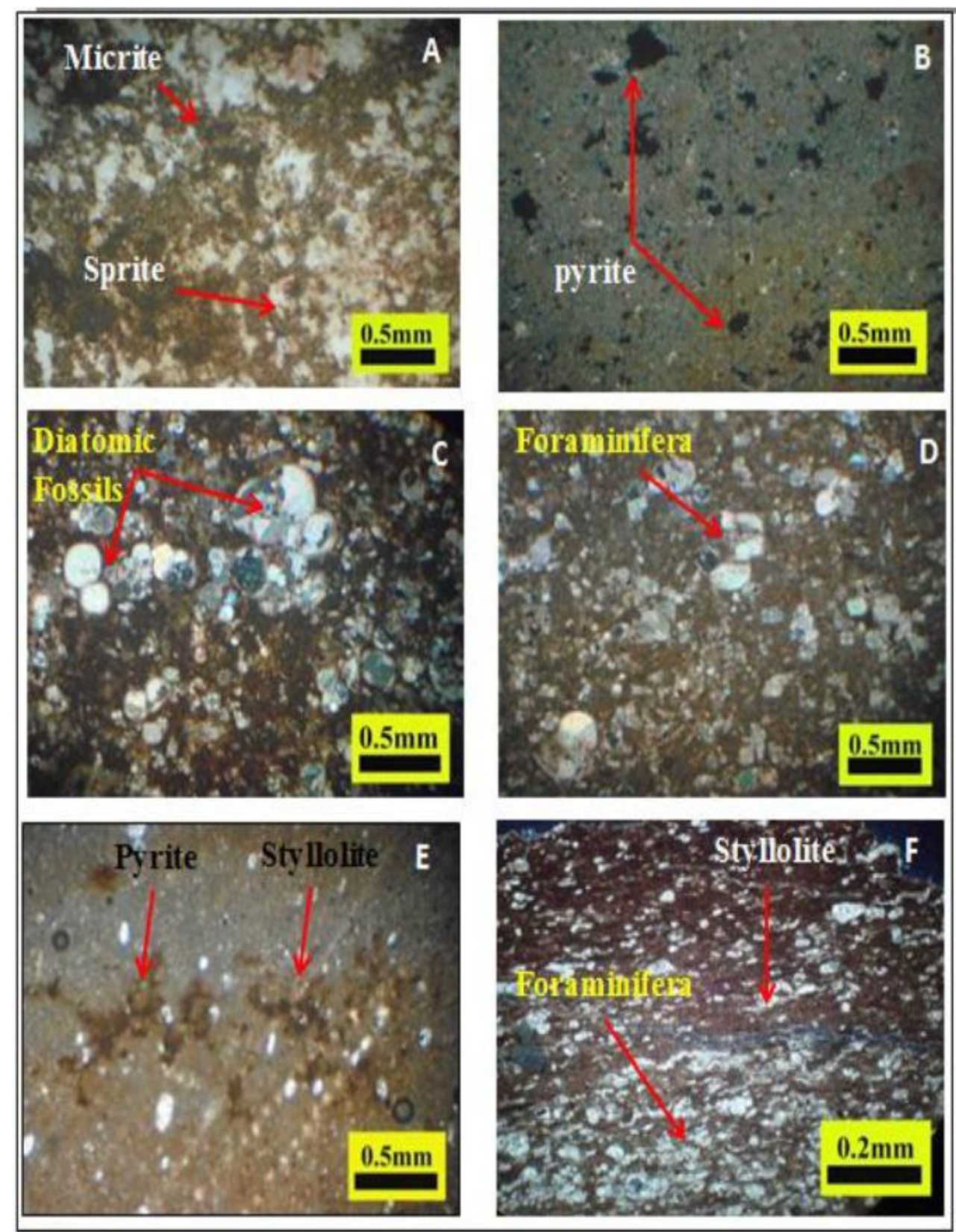

\section{Plate3}

A: Micrite and sparry grains supported in Pushen section.

B: Vugs with pyrite in Pushen village section.

C: planktonic foraminifera like Globotraaca with blocky cement fill in spar in Pushen section.

D: planktonic foraminifera like Globotraaca, Globigerina and Heterohelix in Pushen section.

E: melodic porosity pyrite in Weller village section.

F: Height compaction in the upper part of the Gulneri formation in Dokan section. 


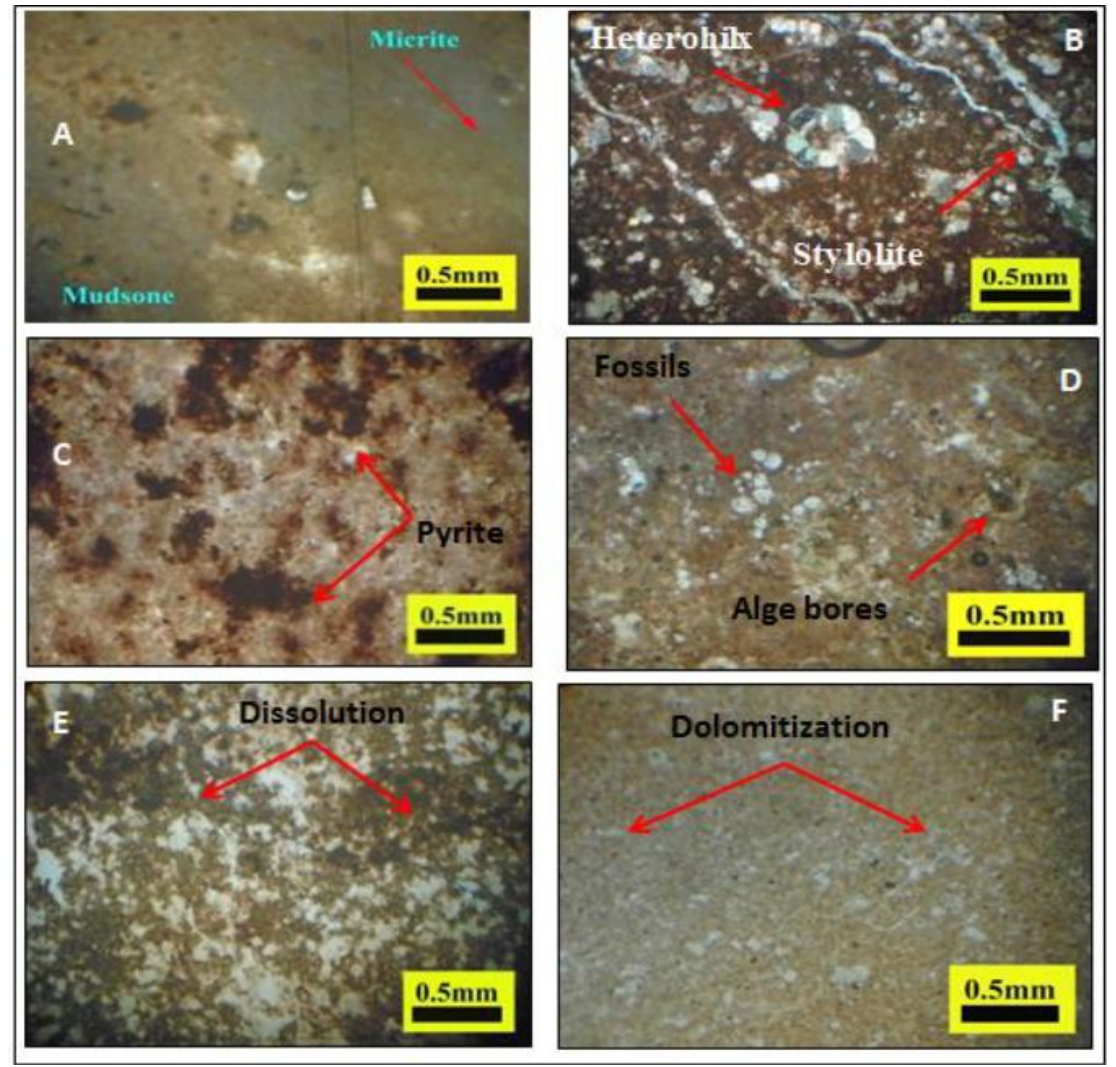

\section{Plate 4}

A: Micrite and mudstone microfacies in Azmir section (sample no.B7).

B: Big crystals filling fractures, vugs, channel and insides keletal grains with irregular stylolite in Pushen village (sample no.D13).

C: Framboidal pyrite in vuggy in Pushen village section (sample no. D7).

D: Planktonic foraminifera with calcium carbonate in the tubes of algalbores in Weller village (sample no.C15).

E: Dissolution processes in Pushen village (sample no. D9).

F: Dissolution processes with a filling of fossil mold and few grains of rhombic dolomite in Azmir section (sample no. B11).

\section{Conclusion}

-Gulneri formation is mainly composed of well-bedded hard limestone interbedded with marl and marly limestone and shale like lithofacies, the main dominant minerals of lithofaciesare calcite followed by quartz; the high percent of insoluble residue indicate the basinal environment of Gulneri formation.

-Palygorskite and illite are clay minerals associated with carbonate and indicate the inner warm marine shelf to deep marine environment.

- The abundance of micrite and the occasional presence of planktonic forams (Globigerina and Globotraaca) suggest that mudstone microfacies deposited in a quite deep basinal environment also the bioclastic wackestone, and bioclastic packstone microfacies reflect the open to deep marine environment of Gulneri formation.

- Gulneri formation was subjected to both mechanical and chemical compaction, the first one represent the preferred orientation of skeletal grains parallel to bedding and the second one represent both irregular low and high amplitude of stylolite.

- The common diagenetic processes that affect the rock of Gulneri formation are silicification, recrystallization, micritization and pyritizati on the presence of framboidal pyrite denotes the predominance of reducing environment during the deposition of Gulneri formation. 


\section{Acknowledgment}

The authors would like to gratefully acknowledge the help, support, and encouragement to Dr. Kamal. $\mathrm{H}$, Karim (Sulaimaniya University, Dept. of Geology) for his continual support and help through filed work, and special thanks to Dr. Hassan Kattof(University of Bagdad), Dept. of Geology for providing some facilities for the analysis of samples.

\section{REFERENCES}

[1] Al-Khafaji, S.J., (1989). Rare-earth element Geochemistry of industrial clay deposits in Iraq. Unpublished M.SC thesis. College of Science, Baghdad University, 136p.

[2] Abawi, T., Hammoudi, R.A., and Al-Khafaf, A.O., (2006). Stratigraphy of the Gulneri Formation (Upper Cretaceous) in the Type section, Dokan Area, NE. Iraq, Iraqi Jour. Earth Sci., Vol.6, No.2, PP.

[3] Bathurst, R.G.C., (1975). Carbonate sediments and their diagenesis, 2nd enlarged., Elsevier, Amsterdam, $658 \mathrm{p}$.

[4] Bellen, R.C.V., Dunnington, H.V., Wetzel, R., and Morton, D., (1959). LexiqueStratigraphique, Interntional. Asie, Iraq, Vol. 3c. 10a, 333 pp.

[5] Berger, W.H.,andPiperD.J.,(1972). Planktonicforaminifera: differential setting and dissolution,Limnology and Oceanography,V.17(2),PP. 275-287.

[6] Boggs, S.Jr., (1995). Principles of sedimentology and stratigraphy, Prentice Hall, New Jersey, 774P.

[7] Bond, D., Wignall, P.B., and Racki, G., (2004). Extent and duration of marine anoxia during the FrasnianFamennian (Late Devonian) mass extinction in Poland, Germany, Austria,and France. Geological Magazine, Vol. 141, pp. 173-193.

[8] Buday, T., and Jassim, S.Z., (1987). Regional geology of Iraq: Tectonismmagmatism, and metamorphism. I.I.Kassab and M.J. Abbas (Eds). Baghdad: Iraqi Geological Survey and Mineral Investigation Press.

[9] Dabbagh, M.E., (2006). Diagenesis of Jurassic Tuwaiq mountain limestone central Saudi Arabia, king Saud.univ., Riyadh,V.19,pp31-58 .

[10] De Groot, K., (1967). Experimental dolomitization texture. Sed. Petrol.,V 37 ,pp1216-1220.

[11] Dunham, R.J., (1962). Classification of carbonate rocks according to depositional texture. In Ham, W. E. (ed.), Classification of carbonate rocks. A symposium Am. Ass. Petrol. Geologists, Memoir 1, Talusa, Oklahoma, U.S.A, pp108-121.

[12] Ellingboe, J., and Wilson, J., (1964). Quantitativeseparation of non-carbonate minerals from carbonate minerals. Jour. Side. Petrol.,

[13] Engelhardt, W.V., (1977). The origin of sediments and sedimentary rocks, E.SchweizerPorscheVerlagsuch handing (NagelaU.ober miller),Stuttgart,359p.

[14] Flugel, E., (2004). Microfacies of carbonate rocks. Springer-Verlag, Berlin, 976 p.

[15] Flugel, E., (2010). Microfacies of Carbonate Rocks, Second edition, Springer Heidelberg, 1006P.

[16] Greensmith, J.T., (1978). Petrology of the Sedimentary Rocks, George Allen \&Unwin, London, 241P.

[17] Henderson, G.M., (2002). New oceanic proxies for paleoclimate. Earth and Planetary Science Letters, Vol. 203, pp. 1-13.

[18] Karim, K.H., and Taha, Z.A., (2009). Tectonic history of the Arabian platform during Late Cretaceous, An example from Kurdistan region, NE Iraq Iranian Journal of Earth Sciences, vol. 1, pp. 1-14.

[19] Karim, K.H., Koyi, H., Baziany, M.M., and Hessami, K., (2011). The significance of angular unconformities between Cretaceous and Tertiary strata inthenorthwestern segment of the Zagros foldthrust belt, Kurdistan Region, NE-Iraq. Geological Magazine, Cambridge University Press, 148 (5-6): 925939.

[20] Kenter, J.A.M., Harris, P.M., and Porta, G.D., (2004). Steep microbial boundstone dominated platform margin-examples and implications. Sedimentary Geology, 178, pp.5-30.

[21] Larsen, G., and Chilinger, G.V., (1979). Introduction diagenesis of sediments and rocks, in Larsen, G.,andChilinger, G.V., eds., Diagenesis in sediments and sedimentary rocks. Development in sedimentology 25A. Elsevier Publ. Co. Amsterdam, 1-29 p.

[22] Longan, B.W., Semeniuk, V., (1976). Dynamic metamorphism, Processes, and products in Devonian carbonate rocks. Canning Basin, Western Australia. Geol. Soc. Australia spec. publ. 6, P. 138.

[23] Longman, M.W., (1980). Carbonate diagenesis textures from the near surface diagenetic environment. AAPG. Bull., Vol. 64, No. 4, 461-487 p.

[24] Lumsden, D.N., (1974). Relationships among insurable residue, dolostone and limestone facies.Jour. sed. Petrol. Vol.44, PP: 450-455. 
[25] Ma'ala, K.A., Hassan, K.A., and Al-khateeb, A.A.G., (2004). Semi-detailed geological survey of JabalAzmer -Choarta area, state company of geological survey and mining.Report No.2885.

[26] Nichols, C., (2009). Sedimentary and stratigraphy, whily and sors, New York, 255-246.

[27] Ostrom, M.E., (1961). Separation of clay minerals from Carbonate Rocks by using acid. Jour. Sed .petrol. 31: 123-129.

[28] Potter, P.E, Maynard, J.B., and pryor, W.A., (1980). Sedimentology of shale. Spring- Verlag, Berling, $303 p$.

[29] Rhymond, L.A., (1995). Petrology: The study of igneous, sedimentary, and metamorphic rocks, Wm.C. Brown publishers, 470P.

[30] Selley, R.C., (2000). Applied Sedimentology, Academic Press. USA .521p.

[31] Shearman,D.J.,andShirmuhammad,N.H.,(1969).Distributionof StrontiumindolomitesfromtheFrenchJura,Nature.Vol.223,pp.606-608.

[32] Shinn, D.E., (1969). Submarine Lithification of Holocene Carbonate Sediments in

[33] Sissakian,V.K.,(2000).GeologicalmapofIraq.SheetsNo.1,Scale1:1000000,3rdEdit.GEOSURV, Baghdad,Iraq.Stratigraphic, International, Asia, Iraq, Vol.3c.10a, 333PP.

[34] Suits, N.S., and Wilkin, R.T., (1998). Pyrite Formation in the Water Column and Sediments of a meromictic Lake; Geology (Boulder), Vol.26, pp. 1099-1102.

[35] Trurnit, P., (1968). Pressure solution phenomenon in detrital rocks, Sed. Geol., Amsterdam, V.2, pp89114.

[36] Tucker, M.E., (1988). Techniques in Sedimentology First published 394P.

[37] Wilkin, R.T., and Arthur, M.A., (2001). Variations in pyrite texture, sulfur isotope composition, and iron systematics in the Black Sea: evidence for late Pleistocene to Holocene excursions of the $\mathrm{O} 2-\mathrm{H} 2 \mathrm{~S}$ redox transition. Geochimica et CosmochimicaActa, Vol. 65, pp. 1399-1416.

[38] Wilkin, R.T., Barnes, H.L., and Brantley, S.L., (1996). The size distribution of framboidal pyrite in modern sediments: an indicator of redox conditions. Geochimica et CosmochimicaActa, Vol. 60, pp. 3897.

[39] Wilson, J.D., 1975. Carbonate Facies in Geological History, Springer Verlag, Berlin, 471 P.

Citation: Al-Khafaji S. J., Al-Saad A.L., (2019)" Mineralogy and Petrography of Gulneri Formation in Sulaimaniya Area, North East of Iraq, (Kurdistan)", Southeast Cameroon, International Journal of Mining Science (IJMS), 5(2), pp.1-13, DOI: http://dx.doi.org/10.20431/2454-9460.0502001

Copyright: () 2019 Authors. This is an open-access article distributed under the terms of the Creative Commons Attribution License, which permits unrestricted use, distribution, and reproduction in any medium, provided the original author and source are credited 